\title{
Prospects of botanical pesticides in management of Iroko gall bug, Phytolyma fusca (Hemiptera, Psylloidea) under laboratory and field conditions
}

\author{
Juliana Amaka Ugwu(D
}

\begin{abstract}
Background: Iroko gall bug, Phytolyma fusca Walker, is a major insect pest of Milicia excelsa (Iroko) seedling hampering its propagation in West Africa. Milicia excelsa is an indigenous forest timber tree in the tropical rain forest of West Africa with a very high value in international trade due to its wood quality. Sustainable management of $P$. fusca infestations on Iroko seedlings have not been achieved due to their cryptic nature and multivoltine generations. This study evaluated the residual and contact effects of crude ethanol and aqueous extracts of four plants (Azadirachta indica, Jatropha curcas, Piper guineense, and Aframomum melegueta) on adult P. fusca in the laboratory and field.
\end{abstract}

Results: All the extracts had residual effects and contact effects on adult insects in the laboratory at $75 \%$ and $100 \%$ concentrations of applications. Azadirachta indica, P. guineense, and A. melegueta gave 80-100\% adult mortality at both concentrations in the laboratory; their efficacies were comparable to cypermethrin. The ethanol extracts of $P$. guineense and $A$. indica were more effective than other extracts in protecting the seedlings against Phytolyma infestations in the field. They significantly $(p<0.01)$ reduced infestation compared to other extracts and control. Ethanol extracts of the tested plant materials were more effective than their aqueous extracts both in the laboratory and field.

Conclusion: The results proved that $P$. guineense and $A$. indica extracts were very potent and promising in protecting Milicia excelsa seedlings against Phytolyma fusca infestations and they can be used in the early management of Phytolyma infestations in the field.

Keywords: Biopesticides, Toxicity, Milicia excelsa, Phytolyma fusca, Insect pest, Control

\section{Background}

Phytolyma species Psyllidae is a key insect pest of Iroko plant (Milicia excelsa) seedlings in sub Saharan Africa hampering the cultivation of Milicia excelsa in plantations in the region (Ugwu \& Omoloye, 2014a). Recent report by Ugwu, Ombura, Salifu, and Khamis (2019) using morphometric and molecular characterization has confirmed the species found in Nigeria to be Phytolyma fusca (Walker).

\section{Correspondence: dr.amaka2013@gmail.com}

Department of Forest Technology, Federal College of Forestry, Forestry

Research Institute of Nigeria, P.M.B. 5087, Jericho Hills, Ibadan, Oyo State, Nigeria

\section{Springer Open}

Phytolyma fusca attack the Milicia seedlings by the adult psyllid laying eggs on the young leaves and the buds which later results in gall formation on the young shoots and buds when the eggs are hatched (Ofori \& Cobbinah, 2007; Ugwu, Omoloye, 2014a). The gall formation is initiated as soon as the eggs are hatched into first instar nymphs, as they puncture the young shoot or leaf to feed. Galls usually enlarge to enclose nymphs until they become turgid to split and release the adult flies which later results to dieback of leaves down to the stems (Ugwu and Omoloye, 2014). Repeated attacks on young Millicia seedlings disrupt the growth processes resulting to growth retardation 
and in most cases lead to total death or dieback of the seedlings (Cobbinah, 1993; Ofori et al., 2007; Ugwu \& Omoloye, 2013; Wagner, Atuahene, \& Cobbinah, 1991). Sustainable management of this pest for the past years has not recorded appreciable success due to the cryptic nature of the pest and its multiple generations. However, a promising result of $80-100 \%$ seedling survival after 2 years in the field using barrier nets in combination with carbofuran and diamethoate has been reported Ugwu \& Omoloye, 2014b). This approach may not be sustainable for a long period especially on a large-scale basis and are not fully ecologically friendly. Use of botanical pesticides in pest control has recently gained tremendous interest due to problems associated with the use of synthetic pesticides. The pesticides residues on the crops and persistence in the environment as well as their toxicity to the non-target organisms has necessitated the need for the search for effective bio-pesticide that are biodegradable with higher selectivity and suitable for use in integrated management programs (Guleria \& Tiku, 2009). Several plants have been screened for their insecticidal properties against many insects pests both in the field and in storage. Notable success has been recorded using various plants with bioactive compounds to manage human diseases as well as pests and diseases of various agricultural crops (Karpagam \& Devaraj, 2011; Thiruppathi, Ramasubramanian, Sivakumar, \& Thirumalaiarasu, 2010). Many botanical pesticides from different plant sources like pyrethrum, neem, sabadilla, tobacco, and ryania has been successfully isolated and commercialized (Arnason et al., 2012). Botanical pesticides shows different modes of action on the target pests like toxicity effect, growth disruption, and repellence as well as physical alteration thus offer the appropriate crop pest management alternatives (Kushram, Yadu, Sahu, Kulmitra, \& Kumar, 2017; Rattan, 2010). Neem, Azadirachta indica A. Juss., a sub-tropical tree native to the arid areas of Asia and Africa is a very good source of numerous insecticidal alkaloids (Saha, Islam, \& Khan, 2006). It has great potential in the management of several field pests of agricultural crops, medicine, and environmental protection. Piper guineese is also very potent botanical insecticides against many pests and diseases of agricultural importance and have been found very effective even in their crude forms (Abiala, Ayandeko, \& Odebode, 2015; Ajayi \& Olufolaji, 2008; Ugwu, 2020). Similarly, Jatropha curcas and Aframomum melegueta have been used in the management of many agricultural pests and diseases (Sabbour and Abd-El-Raheem (2013). Ugwu, Umeh, Ojo, Aderemi, \& Shaib-Rahim, 2015; Ugwu, Umeh, \& Omoloye, 2017; Ugwu, 2020). Thus, this study investigated the efficacy of crude and aqueous extracts of four plants: Azadirachta indica, A. Juss Jatropha curcas L., Piper guineense
Schumach. \& Thonn and Aframomum melegueta, K. Schum against $P$. fusca under laboratory and field conditions.

\section{Methods \\ Study sites}

The experiment was conducted at Biology Laboratory of the Federal College of Forestry (FCF) and at the experimental field of the institution during the rainy season of 2019. The Federal College of Forestry Ibadan is located at latitude $7^{\circ}$ and $9^{\circ} \mathrm{N}$ longitude $3^{\circ}$ and $58^{\circ} \mathrm{E}$ of Greenwich Meridian Time (GMT) with annual rainfall of 1300 to $1500 \mathrm{~mm}$ and relative humidity of a 80 to $85 \%$ average (FRIN, 2017).

Collection of Milicia excelsa seeds and raising of seedlings $M$. excelsa fruits were collected from the mother plant at the Department of Forest Resources Management, University of Ibadan. The fruits were soaked for $24 \mathrm{~h}$ and the seeds were extracted by macerating the pulp gently and later sieved with fine mesh to separate the seeds from the chaff. The extracted seed were air-dried for 2 weeks and then sown in a nursery tray and placed inside a germinating chamber in a screen house. They were attended to following the standard nursery activities for raising seedlings. The seedlings were later transplanted into 2-L nursery bags at 4 weeks after germination.

\section{Sources of the plant materials and extraction}

Mature fruits of Azadirachta indica, and Jatropha curcas, were collected from the mother plants at Forestry Research Institute of Nigeria, Ibadan, while Piper guineense and Aframomum melegueta seeds were purchased from a local market in Ibadan. The seeds of $A$. indica and $J$. curcas were extracted manually from the fruits and were air-dried on side benches in the laboratory for 2 weeks. The dried seeds were pulverized into powered form using an electric blender (Binatone blender/grinder BLG.450).

Aqueous extracts were prepared by soaking $100 \mathrm{~g} / 200$ $\mathrm{ml}$ of warm water $\left(60{ }^{\circ} \mathrm{C}\right)$ of the powdered samples of plant materials in separate bottles. The mixtures were vortexed at intervals of $30 \mathrm{~min}$ manually for $2 \mathrm{~h}$ and then allowed to stay for $48 \mathrm{~h}$ at room temperature before sieving with muslin cloth to obtain the extracts (Ugwu and Nwaokolo 2020). Ethanol extraction was done by weighing the $100 \mathrm{~g}$ of pulverized samples into Soxhlet extractor and Soxhlet extracted separately using $250 \mathrm{ml}$ of ethanol for minimum of $8 \mathrm{~h}$ according to the methods by Ofuya, Okoye, and Olola (1992). Seventyfive percent concentration was prepared for each extracts from the stock solution for the laboratory assay and field application. 


\section{Sources of adult Phytolyma fusca}

Matured galls were collected from Milicia excelsa at Forestry Research Institute of Nigeria (FRIN) arboretum, and the galls were dissected in the laboratory to remove the adults of Phytolyma fusca for laboratory bioassay.

\section{Laboratory bioassay of the extracts for residual and contact effects on adult $P$. fusca}

The extracts were evaluated for residual actions by applying $1 \mathrm{ml}$ of each extract at $75 \%$ and $100 \% \mathrm{w} / \mathrm{v}$ concentrations on petri dishes lined with filter paper. Petri dishes were left to drain off for 5 min before five newly emerged adult were introduced into each dish. For contact toxicity test, $0.1 \mathrm{ml}$ of each extract was applied to the abdomen of the insects separately and each treatment was replicated 3 times in a completely randomized design (CRD) Fig. 1. The mortality was recorded at 20-min intervals for $24 \mathrm{~h}$.

\section{Field assay of the extracts}

Four-month-old Milicia excelsa seedlings were removed from the screen house and sprayed with $75 \%$ concentration of ethanol and aqueous extracts at $100 \%$ concentration. The sprayed seedlings were exposed to the field for 2 months and monitored for gall formation. Spraying was done at 2-week intervals in completely randomized block design (CRBD) experiment (Fig. 2).

\section{Data collection and analysis}

Data on the mortality of adult $P$. fusca were collected at 20-min intervals for both residual and contact toxicity for the bioassay study in the laboratory for $24 \mathrm{~h}$ and the number of galls was recorded in the field experiment. Data collected were subjected to square root transformation before analysis of variance (ANOVA) and significant means were separated by Duncan multiple range test at 5\% level of significance using ASSISTAT statistical software 7.6 beta.

\section{Results}

Residual and contact effects of ethanol extracts on the mortality of adult $P$. fusca at $75 \%$ concentration

The residual and contact effects of ethanol extracts at $75 \%$ concentration are presented in Table 1.

Ethanol extracts of all the plants evaluated had residual and contact effects on $P$. fusca at 20 min post exposure. Cypermethrin recorded the highest mortality with mean value of 2.33 at $20 \mathrm{~min}$. On the contact assay, $P$. guineense and $A$. indica recorded the highest mortality of $P$. fusca among the extracts with each mean value of 5.00. There were significant differences $(p<0.01)$ on the effect of the treatments from 20 to $40 \mathrm{~min}$ of post exposure. P. guineense and $A$. indica recorded $100 \%$ mortality after $60 \mathrm{~min}$ of exposure for the residual effects. All the extracts recorded $100 \%$ mortality at $80 \mathrm{~min}$ of exposure for the residual assay and at $60 \mathrm{~min}$ of exposure for contact assay, while no mortality was recorded on control experiment. The residual and contact effects of $P$. guineense and $A$. indica were comparable to cypermethrin. There were significant differences $(p<$ 0.01 and $p<0.05)$ on the effects of the treatments at 20 and $40 \mathrm{~min}$, respectively.

\section{Residual and contact effects of ethanol extracts on the mortality of adult $P$. fusca at $100 \%$ concentration}

All the extracts had residual effects and contact effect on P. fusca at $20 \mathrm{~min}$ of post exposure at $100 \%$ concentration (Table 2). P. guineense, A. indica, and cypermethrin gave $100 \%$ mortality on $P$. fusca at for residual assay, while $A$. indica recorded highest mortality in contact effects assay at 20 min of post exposure. There were significant differences $(p<0.01)$ on the effect of all the treatments at 20 and $40 \mathrm{~min}$ of post treatment. All the extracts recorded 100\% mortality at $60 \mathrm{~min}$ of exposure in residual assay while control recorded no mortality.
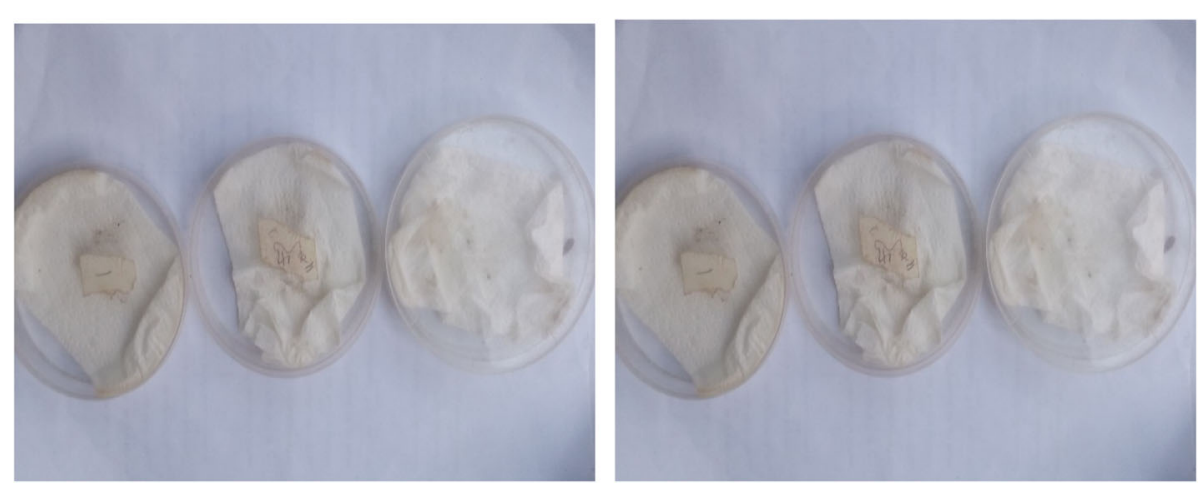

Fig. 1 The experimental layout for laboratory bioassy of the extracts 

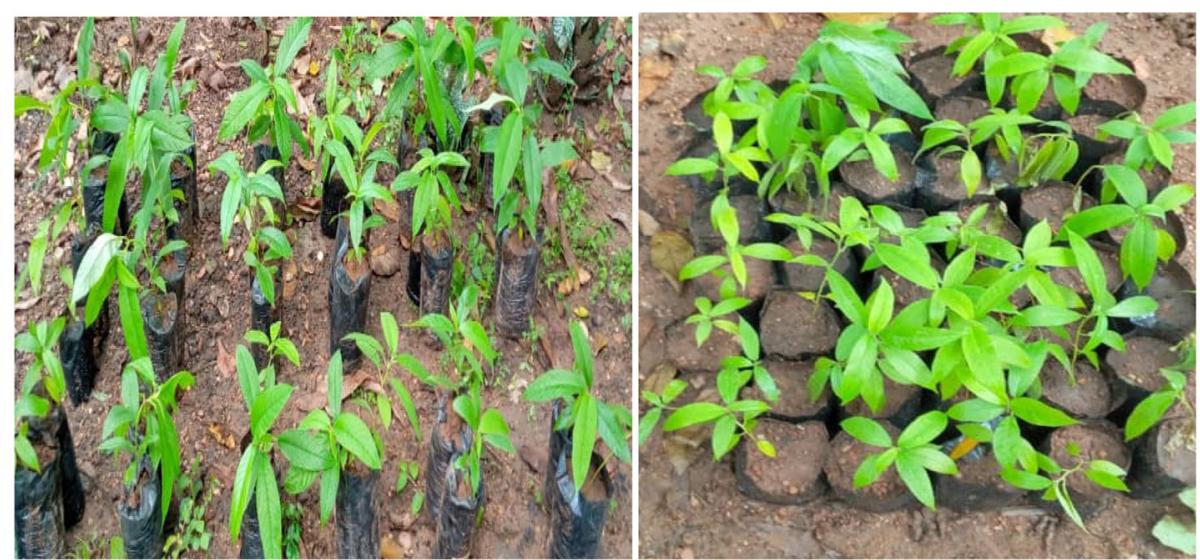

Fig. 2 The experimental layout of field assay of the extracts on 4-month-old Milicia excelsa seedlings

Residual and contact effects of aqueous extracts on the mortality of adult $P$. fusca at $100 \%$ concentration

The residual and contact effects of aqueous extracts at $100 \%$ concentration were less effective compared with ethanol extracts at the early period of post exposure. Their efficacy increased as the time progressed (Table 3). Only A. melegueta recorded $P$. fusca mortality for both residual and contact assays at 20 post treatment, while $A$. indica and $P$. guineense recorded mortality of $P$. fusca for contact assay at same time of exposure. There were significant differences $(p<0.01)$ on the effects of the treatments at $20 \mathrm{~min}, 80 \mathrm{~min}, 100 \mathrm{~min}$, and $24 \mathrm{~h}$ post treatments.

Efficacy of ethanol extracts at $75 \%$ concentration against $P$. fusca infestation on $M$. excelsa in the field

The effects of ethanol extracts at $75 \%$ concentration on $P$. fusca infestations on Milicia excelsa seedlings in the field are presented in Table 4. P. guineense and A. indica were the most effective among all the treatments in protecting $M$. excelsa seedlings against $P$. fusca infestation. No gall was observed on $M$. excelsa seedlings treated with ethanol extracts of both plants for the period of 8 weeks post exposure. Infestation was observed in seedlings treated with A. melegueta and the control after 2 weeks of exposure and progressed through out the period of study. Ethanol extracts of all the plant screened were more effective than cypermethrin in protecting $M$. excelsa against $P$. fusca infestations. There was no significant difference $(\mathrm{p}>0.05)$ on the effects of cypermethrin and control on the infestation of $P$. fusca on Milicia excelsa seedlings.

\section{Efficacy of aqueous extracts at $100 \%$ concentration against $P$. fusca infestations on $M$. excels $a$ in the field} Infestation of $P$. fusca commenced 2 weeks post treatment of aqueous extracts and progressed until the end of the experiment (Table 5). Aqueous extracts of P. guineense protected the $M$. excelsa seedlings for 4 weeks before the onset of infestation and recorded the least

Table 1 Residual and contact effects of ethanol extracts of four plants on the mortality of adult $P$. fusca at $75 \%$ concentration

\begin{tabular}{|c|c|c|c|c|c|c|c|c|c|c|c|c|c|c|}
\hline \multirow[t]{3}{*}{ Treatments } & \multicolumn{14}{|c|}{ TAT $(\min )$} \\
\hline & \multicolumn{2}{|l|}{20} & \multicolumn{2}{|l|}{40} & \multicolumn{2}{|l|}{60} & \multicolumn{2}{|l|}{80} & \multicolumn{2}{|l|}{100} & \multicolumn{2}{|l|}{120} & \multicolumn{2}{|c|}{1440} \\
\hline & $\mathbf{R}$ & C & $\mathrm{R}$ & $\mathrm{C}$ & $\mathrm{R}$ & $C$ & $\mathbf{R}$ & $\mathrm{C}$ & $\mathrm{R}$ & $C$ & $\mathrm{R}$ & C & $\mathbf{R}$ & $\mathrm{C}$ \\
\hline P. guineense & $1.33^{\mathbf{a b c}}$ & $5.00^{a}$ & $2.67^{a}$ & $0.00^{b}$ & 1.00 & 0.00 & 0.00 & 0.00 & 0.00 & 0.00 & 0.00 & 0.00 & 0.00 & 0.00 \\
\hline A. indica & $2.00^{\text {to }}$ & $5.00^{\mathrm{a}}$ & $2.00^{\text {to }}$ & $0.00 \mathrm{~b}$ & 1.00 & 0.00 & 0.00 & 0.00 & 0.00 & 0.00 & 0.00 & 0.00 & 0.00 & 0.00 \\
\hline J. carcus & $0.33^{b c}$ & $3.00^{\mathrm{b}}$ & $3.33^{\mathrm{a}}$ & $1.33^{\mathrm{a}}$ & 1.00 & 0.67 & 0.33 & 0.00 & 0.00 & 0.00 & 0.00 & 0.00 & 0.00 & 0.00 \\
\hline A. melegueta & $1.67^{\mathrm{abc}}$ & $3.33^{b}$ & $1.33^{\mathbf{a b}}$ & $1.00^{\text {to }}$ & 1.33 & 0.00 & 0.67 & 0.00 & 0.00 & 0.00 & 0.00 & 0.00 & 0.00 & 0.00 \\
\hline Cypermethrin & $2.33^{\mathbf{a}}$ & $5.00^{\mathrm{a}}$ & $1.67^{\mathrm{ab}}$ & $0.00^{\mathrm{b}}$ & 0.67 & 0.00 & 0.33 & 0.00 & 0.00 & 0.00 & 0.00 & 0.00 & 0.00 & 0.00 \\
\hline Control & $0.00 \mathrm{c}$ & $0.00^{\mathrm{b}}$ & $0.00^{\mathbf{b}}$ & $0.00^{\mathrm{b}}$ & 0.00 & 0.00 & 0.00 & 0.00 & 0.00 & 0.00 & 0.00 & 0.00 & 0.00 & 0.00 \\
\hline Sig. level & $* *$ & $* *$ & $* *$ & * & Ns & NS & Ns & Ns & Ns & Ns & Ns & Ns & Ns & Ns \\
\hline
\end{tabular}

Means with same letters within the same column are not significantly different. Ns not significant, $R$ residual effects, $C$ contact effects 
Table 2 Residual and contact effects of ethanol extracts of four plants on the mortality of adult $P$. fusca at 100\% concentration

\begin{tabular}{|c|c|c|c|c|c|c|c|c|c|c|c|c|c|c|}
\hline \multirow[t]{3}{*}{ Treatments } & \multicolumn{14}{|c|}{ TAT (min) } \\
\hline & \multicolumn{2}{|l|}{20} & \multicolumn{2}{|l|}{40} & \multicolumn{2}{|l|}{60} & \multicolumn{2}{|l|}{80} & \multicolumn{2}{|l|}{100} & \multicolumn{2}{|l|}{120} & \multicolumn{2}{|c|}{1440} \\
\hline & $\mathbf{R}$ & C & $\mathbf{R}$ & C & $\mathbf{R}$ & C & $\mathbf{R}$ & $\mathrm{C}$ & $\mathbf{R}$ & C & $\mathbf{R}$ & $C$ & $\mathbf{R}$ & $C$ \\
\hline$P$. Guinean & $5.00^{a}$ & $4.67^{a}$ & $0.00^{\mathrm{b}}$ & 0.00 & 0.00 & 0.00 & 0.00 & 0.00 & 0.00 & 0.00 & 0.00 & 0.00 & 0.00 & 0.00 \\
\hline A. indicates & $5.00^{\mathrm{a}}$ & $5.00^{\mathbf{a}}$ & $0.00^{\mathrm{b}}$ & 0.00 & 0.00 & 0.00 & 0.00 & 0.00 & 0.00 & 0.00 & 0.00 & 0.00 & 0.00 & 0.00 \\
\hline J. carcus & $3.67^{\mathrm{ab}}$ & $4.33^{\mathbf{b}}$ & $1.00^{\text {to }}$ & 0.67 & 0.33 & 0.00 & 0.00 & 0.00 & 0.00 & 0.00 & 0.00 & 0.00 & 0.00 & 0.00 \\
\hline A. melegueta & $2.33^{\mathbf{b}}$ & $4.67^{\mathrm{a}}$ & $2.00^{\mathrm{a}}$ & 0.33 & 0.67 & 0.00 & 0.00 & 0.00 & 0.00 & 0.00 & 0.00 & 0.00 & 0.00 & 0.00 \\
\hline Cypermethrin & $5.00^{a}$ & $5.00^{\mathbf{b}}$ & $0.00^{\mathrm{b}}$ & 0.00 & 0.00 & 0.00 & 0.00 & 0.00 & 0.00 & 0.00 & 0.00 & 0.00 & 0.00 & 0.00 \\
\hline Control & $0.00^{c}$ & $0.00^{\mathbf{b}}$ & $0.00^{\mathrm{b}}$ & 0.00 & 0.00 & & 0.00 & & 0.00 & & 0.00 & & 0.00 & \\
\hline Sig. level & $* *$ & $* *$ & $* *$ & Ns & Ns & Ns & Ns & Ns & Ns & Ns & Ns & Ns & Ns & Ns \\
\hline
\end{tabular}

Means with same letters within the same column are not significantly different. Ns not significant, $R$ residual effects, $C$ contact effects, TAT time after treatments *Significant at $5 \%$

**Significant at $1 \%$ by Duncan multiple range test (DMRT)

number of galls at the end of the study. P. guineense significantly $(p<0.01)$ reduced $P$. fusca infestation more than other extracts and cypermethrin, while $A$. indica reduced $P$. fusca infestation more than cypermethrin. There were no significant differences on the number of galls recorded on $M$. excelsa seedlings treated with cypermethrin, J. curcas, A. melegueta, and control.

\section{Percentage mortality of $P$. fusca at $24 \mathrm{~h}$ post treatment with different concentrations of ethanol and aqueous extracts in the laboratory}

All the ethanol extracts of the screened plants recorded $100 \%$ mortality of $P$. fusca in the laboratory for both contact and residual assay at $24 \mathrm{~h}$ post treatment (Fig. 3). Their efficacies were comparable to cypermethrin (synthetic insecticide). Aqueous extracts of $P$. guineense and $A$. melegueta were more effective than other extracts for the residual effects compared to contact effects. They both recorded $100 \%$ mortality on the residual effects at $24 \mathrm{~h}$ post treatment. No mortality was recorded on the control experiment for both residual and contact assays at $24 \mathrm{~h}$ post exposure.
Percentage infestation of $P$. fusca on $M$. excelsa seedlings treated with ethanol and aqueous extracts in the field.

The ethanol extracts of $P$. guineense and $A$. indica were the most effective among the extracts in protecting $M$. excelsa seedlings against $P$. fusca infestation in the field (Fig. 4). They both recorded $0 \%$ infestation at the end of the experiment. Their aqueous extracts were also effective compared to other extracts, with P. guineense (5.13\%) infestation being the most effective followed by $A$. indica (13.23\%). A. melegueta extracts was least effective among the plant extracts tested against $P$. fusca on $M$. excelsa in the field with $23.08 \%$ and $30.61 \%$ infestation for ethanol and aqueous extracts, respectively. Control experiment recorded highest percentage infestation for aqueous extracts. Ethanol extracts of all the screened plants were more effective than their aqueous extracts in protecting $M$. excelsa against $P$. fusca infestation in the field.

\section{Discussion}

The results of this study have established the potential of the four plant extracts tested against $P$. fusca in the laboratory and the potency of ethanol extracts of $P$.

Table 3 Residual and contact effects of aqueous extracts of four plants on the mortality of adult P. fusca at 100\% concentration

\begin{tabular}{|c|c|c|c|c|c|c|c|c|c|c|c|c|c|c|}
\hline \multirow[t]{2}{*}{ Treatments } & \multicolumn{14}{|c|}{ TAT (min) } \\
\hline & $\mathbf{R}$ & $\mathrm{C}$ & $\mathbf{R}$ & C & $\mathbf{R}$ & $\mathrm{C}$ & $\mathbf{R}$ & $\mathrm{C}$ & $\mathbf{R}$ & $C$ & $\mathbf{R}$ & $\mathrm{C}$ & $\mathbf{R}$ & $\mathrm{C}$ \\
\hline P. Guinean & $0.00^{c}$ & $0.67^{\mathbf{b c}}$ & $0.67^{\mathrm{ab}}$ & 0.33 & 0.00 & 0.00 & 0.67 & $0.33^{\mathbf{b}}$ & $1.33^{a}$ & $1.67^{\mathrm{a}}$ & 1.67 & 0.33 & 1.67 & 1.00 \\
\hline A. indicates & $0.00^{c}$ & $1.00^{\mathbf{b}}$ & $0.67^{a b}$ & 0.00 & 0.33 & 1.33 & 0.33 & $0.00^{\mathbf{b}}$ & $0.33^{b}$ & $1.67^{\mathrm{a}}$ & 1.00 & 0.33 & 1.33 & 0.00 \\
\hline J. carcus & $0.00^{c}$ & $0.00^{c}$ & $0.00^{\mathrm{b}}$ & 1.00 & 0.33 & 1.00 & 1.33 & $1.67^{\mathrm{a}}$ & $1.33^{\mathrm{a}}$ & $0.33^{\mathbf{b}}$ & 0.33 & 0.67 & 1.33 & 0.67 \\
\hline A. melegueta & $0.67^{a}$ & $1.33^{\mathbf{a}}$ & $1.00^{\mathrm{a}}$ & 0.67 & 0.67 & 1.00 & 1.33 & $1.67^{\mathrm{a}}$ & $0.00^{b}$ & $0.00^{\mathbf{b}}$ & 0.67 & 0.00 & 0.67 & 0.00 \\
\hline Cypermethrin & $5.00^{b}$ & $5.00^{\mathbf{b}}$ & $0.00^{b}$ & 0.00 & 0.00 & 0.00 & 0.00 & $0.00^{\mathbf{b}}$ & $0.00^{b}$ & $0.00^{\mathbf{b}}$ & 0.00 & 0.00 & 0.00 & 0.00 \\
\hline Control & $0.00^{c}$ & $0.00^{c}$ & $0.00^{\mathrm{b}}$ & 0.00 & 0.00 & 0.00 & 0.00 & $0.00^{\mathbf{b}}$ & $0.00^{\mathrm{b}}$ & $0.00^{\mathbf{b}}$ & 0.00 & 0.00 & 0.00 & 0.00 \\
\hline Sig. level & $* *$ & $* *$ & $* *$ & Ns & Ns & Ns & Ns & $* *$ & * & $* *$ & Ns & Ns & Ns & Ns \\
\hline
\end{tabular}

Means with same letters within the same column are not significantly different. Ns not significant, $R$ residual effects, $C$ contact effects, TAT time after treatments **Significant at $5 \%$

**Significant at $1 \%$ by Duncan multiple range test (DMRT) 
Table 4 Effect of ethanol extracts on the number of galls on Milicia seedlings in the field at $75 \%$ concentration

\begin{tabular}{|c|c|c|c|c|c|c|c|c|}
\hline \multirow[t]{2}{*}{ Treatments } & \multicolumn{8}{|c|}{ WHAT } \\
\hline & 1 & 2 & 3 & 4 & 5 & 6 & 7 & 8 \\
\hline P. Guinean & 0.00 & $0.00^{b}$ & $0.00^{\mathrm{a}}$ & $0.00^{\mathbf{b}}$ & $0.00^{\mathbf{b}}$ & $0.00^{\mathbf{b}}$ & $0.00^{\mathbf{b}}$ & $0.00^{\mathbf{b}}$ \\
\hline A. indicates & 0.00 & $0.00^{b}$ & $0.00^{\mathrm{a}}$ & $0.00^{\mathbf{b}}$ & $0.00^{\mathbf{b}}$ & $0.00^{\mathbf{b}}$ & $0.00^{\mathbf{b}}$ & $0.00^{\mathbf{b}}$ \\
\hline J. carcus & 0.00 & $0.00^{b}$ & $1.00^{\mathrm{a}}$ & $\begin{array}{l}1.33 \\
\mathbf{a b}\end{array}$ & $\begin{array}{l}2.00 \\
\text { to }\end{array}$ & $\begin{array}{l}2.67 \\
\mathbf{a b}\end{array}$ & $\begin{array}{l}3.33 \\
\mathbf{a}\end{array}$ & $\begin{array}{l}3.67 \\
\mathbf{a}\end{array}$ \\
\hline A . melegueta & 0.00 & $\begin{array}{l}0.33 \\
a\end{array}$ & $\begin{array}{l}0.67 \\
\mathbf{a}\end{array}$ & $\begin{array}{l}1.00 \\
\text { to }\end{array}$ & $\begin{array}{l}1.67 \\
a b\end{array}$ & $\underset{\mathbf{a b}}{2.33}$ & $\begin{array}{l}3.33 \\
\mathbf{a}\end{array}$ & $\begin{array}{l}3.67 \\
a\end{array}$ \\
\hline Cypermethrin & 0.00 & $0.00^{b}$ & $\begin{array}{l}0.33 \\
\mathbf{a}\end{array}$ & $\begin{array}{l}1.00 \\
\text { to }\end{array}$ & $\begin{array}{l}1.67 \\
a b\end{array}$ & ${ }_{\mathbf{a b}}^{2.33}$ & $3.00^{\mathbf{a}}$ & $\begin{array}{l}3.33 \\
\mathbf{a}\end{array}$ \\
\hline Control & 0.00 & $1.00^{\mathrm{a}}$ & $\begin{array}{l}1.67 \\
a\end{array}$ & $2.00^{\mathrm{a}}$ & $3.00^{\mathrm{a}}$ & $3.33^{\mathrm{a}}$ & $4.00^{\mathbf{a}}$ & $\begin{array}{l}4.67 \\
\text { a }\end{array}$ \\
\hline Sig. level & Ns & $* *$ & $* *$ & $* *$ & ** & $* *$ & $* *$ & $* *$ \\
\hline
\end{tabular}

Means with same letters within the same column are not significantly different. Ns not significant, WAT weeks after treatments *Significant at $5 \%$

**Significant at $1 \%$ by Duncan multiple range test (DMRT)

guineense and $A$. indica in protecting $P$. fusca infestations on M. excelsa in the field.

Golob, Moss, and Males (1999) reported that powder, oil, hexane, and acetone extracts of $P$. guineense were effective against various insects of crops like maize or cowpea in storage. Piper guineense has also been reported to be effective against both field and stored insect pests by several researchers. Fasakin and Aberejo (2002) reported that powdered form of $P$. guineense inhibited egg hatchability and adult emergence of Dermestes maculatus Degeer in smoked catfish (Clarias gariepinus) in storage. Idoko and Adesina (2012) reported that powders of P. guineense caused adult mortality of Callosobrunchus maculatus, inhibited their oviposition on cowpea and suppressed F1 adult emergence. Golob et al.

Table 5 Effect of aqueous extracts on the number of galls on Milicia seedlings in the field at 100\% concentration

\begin{tabular}{|c|c|c|c|c|c|c|c|c|}
\hline \multirow[t]{2}{*}{ Treatments } & \multicolumn{8}{|c|}{ WHAT } \\
\hline & 1 & 2 & 3 & 4 & 5 & 6 & 7 & 8 \\
\hline P. Guinean & 0.00 & $0.00^{\mathbf{b}}$ & $0.00^{\mathbf{b}}$ & 0.33 & $0.67^{\mathbf{b}}$ & $1.00^{\mathbf{b}}$ & $1.00^{\mathbf{b}}$ & $1.00^{c}$ \\
\hline A. indicates & 0.00 & $0.00^{\mathbf{b}}$ & $\begin{array}{l}0.67 \\
\mathbf{a}\end{array}$ & 1.00 & $\begin{array}{l}1.33 \\
\text { ab }\end{array}$ & $\begin{array}{l}1.67 \\
\text { ab }\end{array}$ & $\begin{array}{l}2.67 \\
\mathbf{a}\end{array}$ & $2.67^{\mathbf{b}}$ \\
\hline J. carcus & 0.00 & $\begin{array}{l}0.33 \\
\mathbf{a b}\end{array}$ & $0.00^{\mathbf{a}}$ & 1.00 & $\begin{array}{l}2.00 \\
\text { to }\end{array}$ & $3.33^{\mathrm{a}}$ & $\begin{array}{l}3.33 \\
\mathbf{a}\end{array}$ & $4.67^{a}$ \\
\hline A. melegueta & 0.00 & $\begin{array}{l}0.33 \\
\mathbf{a b}\end{array}$ & $\begin{array}{l}1.33 \\
\mathbf{a}\end{array}$ & 1.67 & $\begin{array}{l}2.00 \\
\text { to }\end{array}$ & $\begin{array}{l}2.67 \\
\mathbf{a b}\end{array}$ & $\begin{array}{l}2.67 \\
\mathbf{a}\end{array}$ & $5.00^{\mathbf{a}}$ \\
\hline Cypermethrin & 0.00 & $0.00^{\mathbf{b}}$ & $\begin{array}{l}0.33 \\
\mathbf{a}\end{array}$ & 1.00 & $\begin{array}{l}1.67 \\
\mathrm{ab}\end{array}$ & $\begin{array}{l}2.33 \\
\mathbf{a b}\end{array}$ & $3.00^{\mathbf{b}}$ & $\begin{array}{l}3.33 \\
\mathbf{a b}\end{array}$ \\
\hline Control & 0.00 & $1.00^{\mathbf{a}}$ & $\begin{array}{l}1.67 \\
\mathrm{a}\end{array}$ & 2.00 & $3.00^{\mathbf{a}}$ & $3.33^{a}$ & $4.00^{\mathbf{a}}$ & $4.67^{a}$ \\
\hline Sig. level & Ns & * & $*$ & Ns & $*$ & $* *$ & $* *$ & $* *$ \\
\hline
\end{tabular}

Means with same letters within the same column are not significantly different. Ns not significant, WAT weeks after treatments *Significant at $5 \%$

**Significant at $1 \%$ by Duncan multiple range test (DMRT)
(1999) also reported that P. guineense powder, oil, hexane, and acetone extracts were effective in causing mortality and reducing oviposition of several insects of cowpea and maize. Similarly, Ugwu, Ojo, Aderolu, and Aderemi (2014) also reported that A. indica and P. guineense extracts proved effective against major insect pests of okra in the field. The prospective of products from $A$. indica for the control of field insect pests of eggplant and okra has been proven earlier (Schmutterer, 1995). Adedire and Lajide (2000) reported that A. indica plants have provided a rich source of biologically active chemical compounds which are highly potent in protecting crops against pests. Azadirachta indica derivatives provide broad spectrum control of over 200 species of phytophagous insects (Ascher, 1993). Ojo and Ugwu (2012) also reported that ethanol seed extracts of $A$. indica were very effective in controlling insect pests of Adansonia digitata L. (Baobab) seedlings in the field.

Correspondingly, A. indica was also reported to be very effective in reducing legume pod borer and legume flower thrips infestations in the field (Ugwu, 2020).

The insecticidal properties of $P$. guineense are Piperine which is the main amide active in Piper guineense (Scott et al., 2004).

Azadirachta indica was reported to exhibit broad spectrum functions like repellency, toxicity, growth regulatory, and antifeedant effects against insect pests (Gianotti, Bomblies, Mustata, \& Duchemin, 2008) Ugwu, Omoloye, and Obasaju (2012) also reported that leaf powders of $A$. indica and Cymbopogon citratus were found very effective in protecting Irvingia wombolu kernel against Oryzaephilus mercator in storage. Several reports have been recorded on the efficacy of plant extracts against hemipteran insects, $A$. indica (flowers), and ippia. sidoides extracts caused moderately high mortality rates in adults Podisus nigrispinus (Hemiptera; Pentatomidae) (Poderoso, Correia-Oliveira, Chagas, Zanuncio, \& Ribeiro, 2016) Ethanol leaves extracts of Petiveria alliaceae and Trichilia arborea exhibited high insecticidal effects on eggs and nymphs of B. tabaci (Hemiptera: Aleyroideae) (CruzEstrada, Gamboa-Angulo, Bórges-Argáez, \& RuizSanchez, 2013). Similarly, Fabrick, Yool, and Spurgeon (2020) reported that marigold Tagetes patula significantly reduced oviposition of B. tabaci and caused significantly high mortality of Lygus hesperus Knight (Hemiptera: Miridae) and B. tabaci adults. The plant extracts of $P$. guineense and $A$. indica were found to be more efficacious than cypermethrin synthetic insecticide in protecting $M$. excelsa seedlings against $P$. fusca infestation in the field. These results have confirmed the earlier report by of Basedow et al. (2002) that $A$. indica-based products were more effective than synthetic insecticides for the control of aphids and white flies. Likewise, Ojo and Ugwu (2012) also 


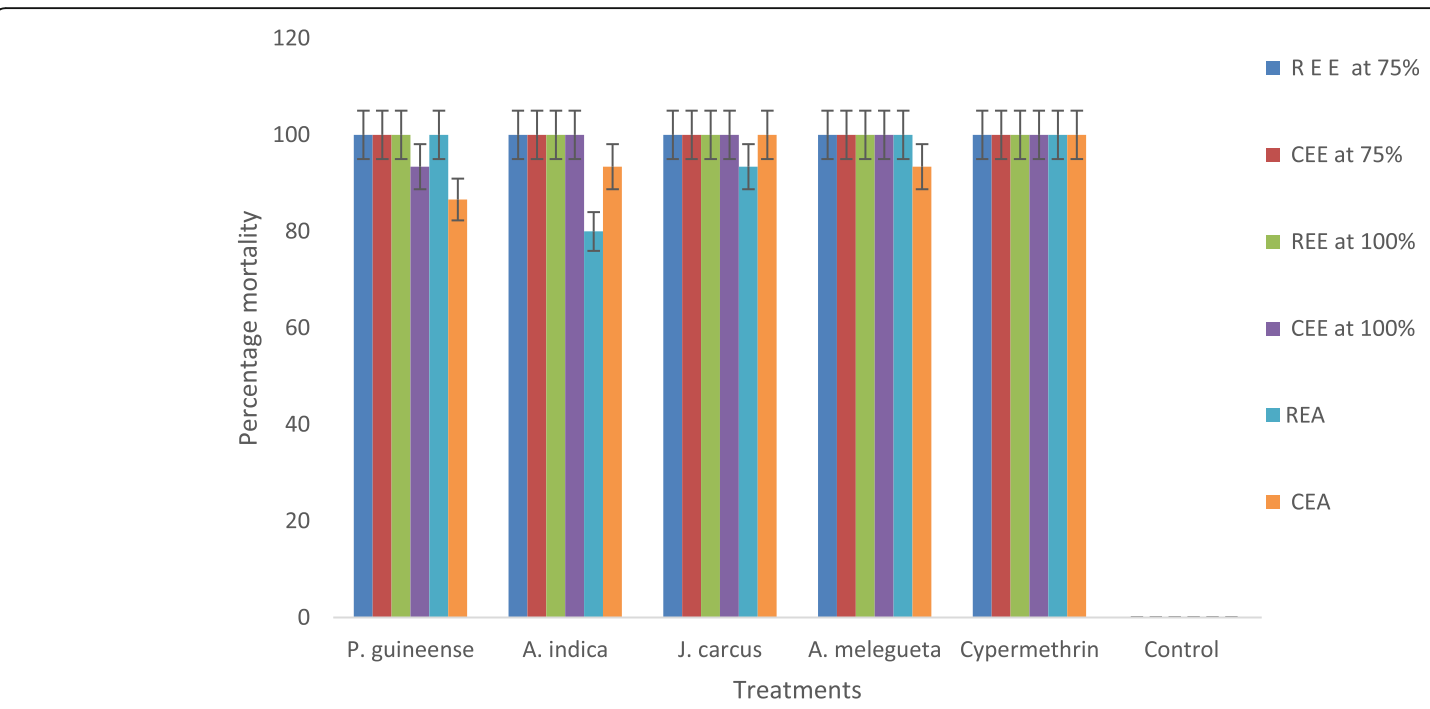

Fig. 3 The mortality percentage of $P$. fusca under the laboratory conditions at $24 \mathrm{~h}$ post treatments with different ethanol concentrations and aqueous extracts (REE, residual effects of ethanol extracts; CEE, contact effects of ethanol extracts; REA, residual effects of aqueous extracts; CEA, contact effects of aqueous extracts)

reported that $A$. indica seed extract was more effective than cypermethrin synthetic insecticides in controlling the insect pests of Adansonia digitata seedling in the field. Petroleum ether seed extracts of $A$. indica, $P$. guineense, A. muricata, and J. curcas were also reported to be more effective than lambdacyhalothrin in against legume flower thrips and legume pod borer on cowpea in the field (Ugwu, 2020; Ugwu et al., 2017).
Ethanol extracts of all the screened plants were more effective than their aqueous extracts in protecting $M$. excelsa against $P$. fusca infestation in the field in this study. This corroborate the report of Huerta, Chiffelle, Puga, Azúa, and Araya (2010) that ethanol leaf extracts of Schinus molle caused greater mortality of elm leaf beetle Xanthogaleruca luteola than the water extracts at similar concentrations

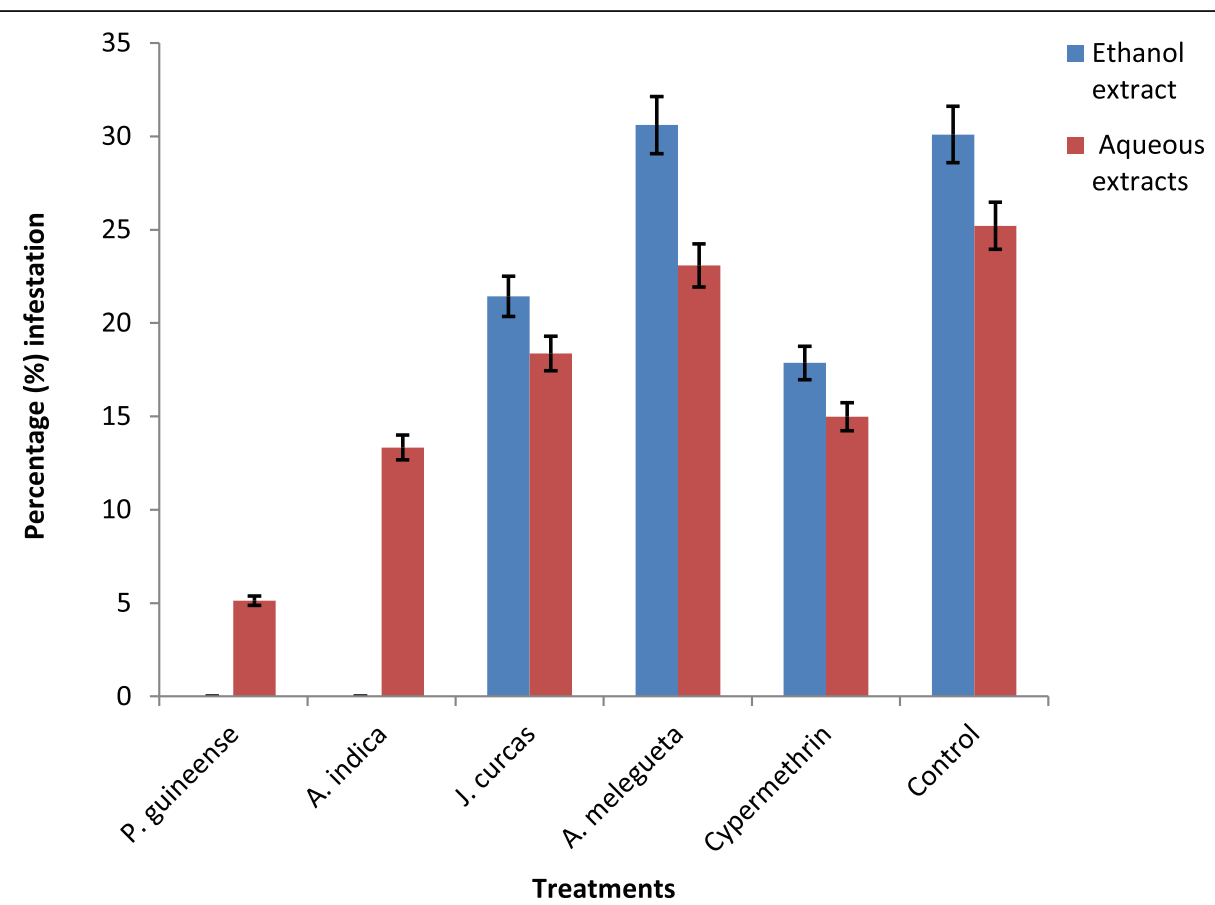

Fig. 4 Effect of ethanol and aqueous extracts on the rate of $P$. fusca infestation on M. excelsa seedlings in the field 


\section{Conclusion}

Ethanol extracts from $P$. guineense and $A$. indica were potent and highly promising in managing $P$. fusca infestation on $M$. excelsa in the field. Their ethanol extracts were more effective than aqueous extracts both in the laboratory and in the field. Results obtained suggest remarkable prospects of developing a bio-insecticide from the combination of $P$. guineese and $A$. indica for integrated pest management (IPM) of P. fusca and other pests of trees species. The use of these plant extracts will reduce dependence on conventional chemical products for pest control and curtail human and environmental hazards associated with the use of synthetic insecticides and also minimize cost of production.

\section{Abbreviations \\ CEA: Contact effects of aqueous extracts; CEE: Contact effects of ethanol extracts; FCF: Federal College of Forestry; FRIN: Forestry Research Institute of Nigeria; GMT: Greenwich Meridian Time; REA: Residual effects of aqueous extracts; TAT: Time after treatments; WHAT: Weeks after treatments}

\section{Acknowledgements}

The author is grateful to the field assistant who helped in maintaining the field during the research activities and to Mr. Idowu, Oludayo Solomon, for his assistance in data collection.

\section{Author's contributions}

The single author is solely responsible for conceptualization, design, and implementation of the research; the analysis of the results; and the writing of the manuscript. The author(s) read and approved the final manuscript.

\section{Funding}

This research did not receive any specific grant from funding agencies in the public, commercial, or not-for-profit sectors.

\section{Availability of data and materials}

All data generated or analyzed during this study are included in this published article.

\section{Declarations}

Ethics approval and consent to participate

Not applicable

\section{Consent for publication}

Not applicable

\section{Competing interests}

The author declares no competing interests.

Received: 11 August 2020 Accepted: 3 May 2021

Published online: 17 May 2021

\section{References}

Abiala, M. A., Ayandeko, F. M., \& Odebode, A. C. (2015). Antifungal effects of selected botanicals on fungal pathogens of watermelon fruit. Archives of Phytopathology and Plant Protection, 48(7), 569-577. https://doi.org/10.1080/ 03235408.2015.1075297.

Adedire, C.O. \& Lajide, L., (2000). Effect of pulverized plant materials on fish damage and growth performance of the fish beetle Dermestes maculatus (Degeer). Book chapter; Conference paper: Entomology in nation building: The Nigerian experience. The Proceedings of ESN 30th Annual Conference held at Kano, Nigeria, 4th-7th October 19992000 pp. 215-218 ref.16 cabdirect.org

Ajayi, A. M., \& Olufolaji, D. B. (2008). The biofungicidal attributes of some plant extracts on Colletotrichum capsici; the fungal pathogen of brown blotch disease of cowpea. Nigerian Journal of mycology, 1(1), 59-65 Google schoolar.
Arnason, J.T., Sims, S.R., \& Scott, I.M. (2012) Natural products from plants as insecticides, phytochemistry and pharmacognosy. www.eolss.net/Sample-A IChapter.aspx/C06/E6-151.

Ascher, K.R. S. (1993). Nonconventional insecticidal effects of pesticides available from the neem tree, Azadirachta indica Archives of Insect Biochemistry and Physiology 22:433-449 https://agris.fao.org/agris-search/search.do?recordID= US9406216, 3-4, DOI: https://doi.org/10.1002/arch.940220311

Basedow, T., Obiewatsch, H.R., Bernal Vega, J.A., Kollmann, S., \& Nicol, C.M.Y. (2002). Control of aphaid and whiteflies (Homoptera; Aphididae and Aleyrodidae) with different neem preparations in laboratory, greenhouse and field: effects and limitations. Journal of Plant Diseases Protection 109, 612-623

Cobbinah, J. R., (1993). Evaluation of five insecticides for the control of Phytolyma lata. Forestry Research Institute Technical Bulletin 3: 35-41. Google scholar Cross ref

Cruz-Estrada, A., Gamboa-Angulo, M., Bórges-Argáez, R., \& Ruiz-Sanchez, E. (2013). Insecticidal effects of plant extracts on immature whitefly Bemisia tabaci Genn. (Hemiptera: Aleyroideae). Electron. J. Biotechnol, 16. https://doi.org/1 0.2225/vol16-issue1-fulltext-6.

Fabrick, J. A., Yool, A. J., \& Spurgeon, D. W. (2020). Insecticidal activity of marigold Tagetes patula plants and foliar extracts against the hemipteran pests, Lygus hesperus and Bemisia tabaci. PLoS ONE, 15(5), e0233511. https://doi.org/10.13 71/journal.pone.0233511.

Fasakin, E. A., \& Aberejo, B. A. (2002). Effect of some pulverised plant materials on the developmental stages of fish beetle, Dermestes maculatus Degeer in smoked catfish (Clarias gariepinus) during storage. Bioresource Technology, 85, 173-177. https://doi.org/10.1016/S0960-8524(02)00058-5.

FRIN (2017). Forestry Research Institute of Nigeria Annual Bulletin, (74 pp). Ibadan: Nigeria.

Gianotti, R.L., Bomblies, A., Mustata, M.\& Duchemin, J.B.,(2008), Efficacy of local neem extract for sustainable malaria vector and source of unique natural product for integrated pest management in African. Medicine Industry and other purposes, pp.385-389. Cross ref.

Golob, P., Moss, C., Males, M., Fidgen, A.\& Evans, J. (1999). The use of spices and medicinals as bioactive protectants for grains. 239 pp. FAO, Rome .Goggle scholar

Guleria, S., \& Tiku, A. K. (2009). Botanicals in pest management: Current status and future perspectives. In R. Peshin, \& A. K. Dhawan (Eds.), Integrated pest management: Innovation-development process, (pp. 317-329). Dordrecht: Springer Netherlands. https://doi.org/10.1007/978.

Huerta, A., Chiffelle, I., Puga, K., Azúa, F., \& Araya, J. E. (2010). Toxicity and repellence of aqueous and ethanolic extracts from Schinus molle on elm leaf beetle Xanthogaleruca luteola. Crop Protection, 29(10), 1118-1123. https://doi. org/10.1016/j.cropro.2010.04.010.

Idoko, J. E., \& Adesina, J. M. (2012). Evaluation of the powder of Piper guineense and pirimiphos-methly $\mathrm{F}$ for the control of cowpea beetle Callosobruchus maculatus (F.). Journal of Agricultural Technology, 8(4), 1365-1374 https:// www.researchgate.net/publication/282866424.

Karpagam, T., \& Devaraj, R. A. (2011). Studies on the efficacy of aloe vera on antimicrobial activity. International Journal of Research in Ayurveda \& Pharmacy, 2(4) https://www.researchgate.net/publication/321070953.

Kushram, T., Yadu, Y. K., Sahu, M. K., Kulmitra, A. K., \& Kumar, R. (2017). Bio efficacy of botanical insecticides against defoliators pests on soybean. International Journal of Current Microbiology and Applied Sciences, 3(3), 2196-2204. https:// doi.org/10.20546/ijcmas.2017.603.250.

Ofori, D. A., Cobbinah, J., \& R. (2007). Integrated approach for conservation and management of genetic resources of Milicia species in West Africa. Forest Ecology and Management, 238(1-3), 1-6. https://doi.org/10.1016/j.foreco.2006. 09.091 Google scholar citation.

Ofuya, T., Okoye, B., \& Olola, A. (1992). Efficacy of a crude extract from seeds of Monodora myristica (Gaertn.) Dunal as surface protectant againstCallosobruchus maculatus (F.) attacking legume seeds in storage. Journal of. Plant Diseases \& Protection, 99(5), 528-532 Google scholar citation.

Ojo, O. M., \& Ugwu, J. A. (2012). Comparative effects of Azadirachta indica A. Juss (neem) seed extract and cypermethrin on insect pests of Adansonia. digitata L. (Baobab) seedlings in Ibadan Southwest Nigeria. African Journal of Agricultural Research and Development, 5(1), 99-103 Google scholar citationsearch.-proquest.com-cross ref.

Poderoso, J. C. M., Correia-Oliveira, M. E., Chagas, T. X., Zanuncio, J. C., \& Ribeiro, G. T. (2016). Effects of plant extracts on developmental stages of the predator Podisus nigrispinus (Hemiptera: Pentatomidae). Florida Entomologist, 99(1), 113-116. https://doi.org/10.1653/024.099.0121. 
Rattan, R. S. (2010). Mechanism of action of insecticidal secondary metabolites of plant origin. Crop protection, 29(9), 913-920. https://doi.org/10.1016/j.cropro.2 010.05.008.

Sabbour, M. M., \& Abd-El-Raheem, M. A. (2013). Repellent effects of Jatropha curcas, canola and Jojoba seed oil, against Callosobruchus maculates (F.) and Callosobruchus chinensis (L.). Journal of Applied Sciences Research, 9, 46784682 https://www.cabdirect.org/cabdirect/abstract/20143043462.

Saha, B.N., Islam, W., \& Khan, A.R.., (2006). Effect of Azadirachtin on the growth and development of the pulse beetle, Callosobruchus chinensis L. Journal. Asiat. Soc. Bangladesh Sci. 32 (1) :69-65. Google scholar

Schmutterer, H. (1995). The neem tree. Source of unique natural products for integrated pest management, medicine, industry and other purposes. New York, Basel, Cambridge: Weinheim. https://doi.org/10.1002/3527603980.

Scott, I.M., Jensen, H., Nicol, R., Lesage, L., Bradbury, R., Sánchez-Vindas, P., Poveda, L., Arnason, J.T., \& Philogène, B.J.R., (2004). Efficacy of piper (Piperaceae) extracts for control of common home and garden insect pests. ec 97, 13901403. https://doi.org/10.1603/0022-0493-97.4.1390, 97, 4, 1390, 1403

Thiruppathi, S., Ramasubramanian, V., Sivakumar, T., \& Thirumalaiarasu, V. (2010). Antimicrobial activity of Aloe vera (L.) Burm. f. against pathogenic microorganisms. J Biosci Res, 1(4), 251-258 http://scholar.google.com/cita tions? user $=$ s3CirUUAAAAJ\&hl=en.

Ugwu, J. A. (2020). Insecticidal activity of some botanical extracts against legume flower thrips and legume pod borer on cowpea Vigna unguiculata L. Walp. The Journal of Basic and Applied Zoology, 81(1), 13. https://doi.org/10.1186/s41 936-020-00153-3.

Ugwu, J. A., \& Nwaokolo, V. M. (2020). Biocidal activity of selected botanicals and Beauveria bassiana on oriental fruit fly, Bactrocera dorsalis (Diptera; Tephritidae). Journal of Research in Forestry, Wildlife and Environment, 12(1). http://www.ajol.info/index.php/jrfwe.

Ugwu, J. A., Ojo, M.O., Aderolu, I. A. \&Aderemi, F. O. (2014). Studies on the efficacy of Azadirachta indica A. Juss, Piper guineense (Schum \& Thonn) seed extracts and chlorpyrifos on insect pests of Abelmoschus esculentus ( $L$ ) Moench in Ibadan South West Nigeria. International Journal of Applied Research and Technology. 3(2): 25 - 31. Google scholar citation. Cross ref.

Ugwu, J. A., Ombura, F.L., Salifu, D., \& Khamis, F.M. (2019). Morphometric and molecular characterization of Iroko gall bug, Phytolyma species (Hemiptera: Psyllidae) From Eastern And Western Nigeria . Journal of Research in Forestry, Wildlife and Environment. 2(2), 57-68. Google scholar

Ugwu, J.A., \& Omoloye, A. A ,(2013). Evaluation of three colours of net barriers against Phytolyma lata (Homoptera; Psyllidae) infestation on Milicia excelsa at seedling stage in the field International Journal of Applied Research and Technology Vol. 2, No. 1, 119 - 124. Google scholar citation

Ugwu, J.A., \& Omoloye, A. A,.(2014a). Biology of Iroko Gall bug, Phytolyma lata Scott (Homoptera Psylidae) on Milicia excelsa (Welw) C.C.Berg. Journal of Entomology 11(1) 34- 41. Google scholar citation

Ugwu, J.A., \& Omoloye A.A. (2014b). Effects of net barrier and synthetic insecticides on Phytolyma lata (Homoptera; Psyllidae) infestation, growth and survival of Milicia excelsa in the field. Journal of Entomology 11(4) 218-224. Google scholar citation, cross ref.

Ugwu, J. A., Omoloye, A. A., \& Obasaju, F. T. (2012). Potentials of Azadirachta indica (A.Juss) and Cymbopogon citratus (Staph) powder for the control of Oryzaephilus mercator (Fauvel) on Irvingia wombolu kernel. Journal of Sustainable Environmental Management, 4, 75-80 Google scholar citation. ma yfeb.com- cross ref.

Ugwu, J.A., Umeh, V. C., Ojo, M.O., Aderemi, F.O., \& Shaib-Rahim, H.O. (2015) Bioefficacy of two plant extracts on lepidopteran insect pests of Corchorus olitorius L. in Ibadan South West Nigeria. Proceedings of the 2nd International Conference and Exhibition of Organization for Women in Science for the Developing World (OWSD) Pp 207-21. Google scholar citation, cross ref.

Ugwu, J. A., Umeh, V. C., \& Omoloye, A. A. (2017). Field evaluation of extracts of four selected plants for the management of Maruca vitrata Fab on cowpea Vigna unguiculata L. Walp. International Journal of Food Safety, Nutrition, Public Health and Technology, 9(7), 60-65 Retrieved from https://search. proquest.com/docview/1953850706?accountid=1136.

Wagner, M. R., Atuahene, S. K. N., \& Cobbinah, J. R. (1991). Forest entomology in West Tropical. Africa: Forest insects of Ghana https://doi.org/10.1007/978-94-01 5-7936-0

\section{Publisher's Note}

Springer Nature remains neutral with regard to jurisdictional claims in published maps and institutional affiliations.

\section{Submit your manuscript to a SpringerOpen ${ }^{\circ}$ journal and benefit from:}

- Convenient online submission

- Rigorous peer review

- Open access: articles freely available online

- High visibility within the field

- Retaining the copyright to your article

Submit your next manuscript at $\boldsymbol{\nabla}$ springeropen.com 